\title{
Exhaled nitric oxide: a new lung function test
}

Nitric oxide (NO) is produced by many cells within the respiratory tract and endogenous NO may play an important signalling role in the physiological control of airway function and in the pathophysiology of airway diseases. ${ }^{1-3}$ Endogenous NO is generated from the amino acid L-arginine by the enzyme NO synthase (NOS), of which three distinct isoforms exist. ${ }^{4}$ Constitutive isoforms are found in endothelial cells (ecNOS or type III) and neurons (nNOS, type I) and are activated by a rise in intracellular calcium, usually in response to physiological stimuli. A third isoform (iNOS, type II) is induced in several cell types by exposure to proinflammatory cytokines and endotoxin and its induction is blocked by glucocorticoids. All three isoforms have been detected in the human respiratory tract. ${ }^{5-8}$

Gustafsson and colleagues first showed that NO can be detected in the exhaled air of animals and normal human subjects ${ }^{9}$ and this has subsequently been confirmed in many studies. ${ }^{10-15}$ Furthermore, the concentration of exhaled NO is increased in patients with inflammatory diseases of the airways such as asthma ${ }^{11216}$ and bronchiectasis. ${ }^{17}$ This suggests that exhaled NO may provide a non-invasive means of monitoring inflammation in the respiratory tract and the measurement of exhaled NO has attracted increasing interest. However, interpretation of exhaled NO measurements may be difficult and there is a wide variation in the reported levels of NO in exhaled air, suggesting that technical factors are important.

\section{How is NO in exhaled air measured?}

Most studies have measured NO in exhaled air by chemiluminescence and detection depends on the photochemical reaction between $\mathrm{NO}$ and ozone generated in the analyser. ${ }^{18}$ Several NO analysers are now commercially available but may need to be converted for online measurement of NO in exhaled air. Most analysers are sensitive to $<1$ part per billion (ppb) of NO and this is adequate for studies of exhaled air. The specificity of exhaled NO measurements by chemiluminescence has recently been confirmed using gas chromatography-mass spectrometry. ${ }^{15} \mathrm{NO}$ may be detected by direct expiration into the analyser or by collection into a reservoir for later analysis. The disadvantage of the latter technique is that there may be variable loss of NO resulting in low and variable measurements.

Several technical factors may affect the measurement of exhaled NO and it is important to specify the technique used so that comparisons between studies is possible. Breath holding results in an increase in exhaled NO which may reflect accumulation of NO in the upper or lower respiratory tracts. ${ }^{13}$ High concentrations of NO have been detected in the upper respiratory tract and nasopharynx, with particularly high concentrations in the paranasal sinuses. ${ }^{19-21}$ This has suggested that exhaled NO may largely reflect NO derived from the upper airways rather than the lower airways. Thus, manoeuvres that block the upper respiratory tract markedly reduce exhaled NO concentrations ${ }^{22}$ and much lower levels of NO are recorded from the lower respiratory tract in tracheotomised patients. ${ }^{1920}$

Factors affecting exhaled NO in normal individuals Breath holding causes a significant rise in exhaled $\mathrm{NO}^{1323}$ and values recorded with a noseclip may be higher due to increased diffusion of NO from the upper respiratory tract into the nasopharynx. In normal individuals there is a significant increase in NO in exhaled air with upper respiratory tract infections. ${ }^{24}$ This may be a reflection of iNOS induction by virus infection in the upper airways. In normal subjects orally administered L-arginine results in an increase in exhaled NO, presumably reflecting increased synthesis due to provision of more substrate for NOS. ${ }^{25}$ The effect of exercise is complex, with a progressive fall in exhaled NO with increasing exercise but correction for increased ventilation shows an increased production of NO. ${ }^{13}$ Hyperventilation at rest also increases exhaled NO, albeit to a lesser extent than exercise. ${ }^{13}$ The mechanism by which exhaled $\mathrm{NO}$ is increased during exercise and hyperventilation is not yet certain, but may involve increased entrainment of $\mathrm{NO}$ from the upper respiratory tract.

Chronic cigarette smokers have lower levels of exhaled NO than non-smokers ${ }^{162627}$ and there is a close correlation between the reduction in exhaled NO and the number of cigarettes smoked. ${ }^{27}$ Active smoking causes a further transient fall in exhaled NO, indicating that exhaled NO is reduced by acute and chronic effects of cigarette smoking. Since cigarettes generate very high concentrations of NO, it is possible that this is due to downregulation of NOS by NO as has been shown for both the constitutive and inducible enzymes. ${ }^{28-30}$ The inhibition of endogenous NO production in the respiratory tract may contribute to reduced mucociliary clearance in smokers, as endogenous NO appears to be important in ciliary beating, ${ }^{31}$ and possibly to an increased susceptibility to lower respiratory tract infections.

\section{Effect of disease on exhaled NO}

Several factors influence the level of $\mathrm{NO}$ in exhaled air (table).

\section{ASTHMA}

An increase in exhaled NO in patients with asthma has been reported in several studies. ${ }^{11} 12^{163233}$ The increase in exhaled NO does not appear to be related to asthma severity or to airway responsiveness (measured by methacholine challenge), and exhaled NO is not increased in asthmatic patients treated with inhaled steroids. ${ }^{12}$ Immunocytochemical staining of bronchial biopsy samples has demonstrated an increased expression of iNOS in epithelial cells in asthmatic subjects compared with non-asthmatic subjects, ${ }^{6}$ suggesting that proinflammatory cytokines present in asthmatic airways have induced its expression resulting in increased NO production in the lower airways. After inhaled allergen challenge in asthmatic patients there is no change of exhaled NO during the early bronchoconstrictor

Factors affecting exhaled nitric oxide (NO)

\begin{tabular}{ll}
\hline Increased NO & Decreased NO \\
\hline Breath holding & Cigarette smoking \\
Exercise/hyperventilation & Pulmonary hypertension \\
L-arginine (oral) & Kartagener's syndrome \\
Upper respiratory tract infections & Glucocorticoids \\
Asthma & NOS inhibitors \\
Allergen challenge (late response) & \\
Bronchiectasis & \\
Cystic fibrosis & \\
Lower respiratory tract infection & \\
\hline
\end{tabular}


response, but a progressive increase during the late response. ${ }^{34}$ In patients who have no late response to allergen (single responders) there is no change in exhaled NO throughout the study period. This suggests that increased $\mathrm{NO}$ is associated with the inflammatory late response and may be a reflection of iNOS expression in response to inflammatory cytokines. In sensitised guinea pigs allergen challenge is associated with increased NO production during the late response and this is preceded by iNOS mRNA expression. ${ }^{35}$ Whether increased NO production is merely a marker of the cytokine-mediated inflammation or contributes to the airway narrowing (secondary to vasodilation and increased plasma exudation) during the late response is not yet certain, and studies with NOS inhibitors are needed. By contrast, there is no increase in exhaled NO after bronchoconstriction induced by histamine (direct effect on airway smooth muscle) or by adenosine (via activation of airway mast cells). ${ }^{33} 36$ There is also an increase in exhaled NO during exacerbations of asthma ${ }^{337}$ and when the maintenance dose of inhaled glucocorticoids is reduced. ${ }^{38}$ The increased levels of exhaled NO during an acute exacerbation of asthma are reduced within 48 hours of starting methylprednisolone treatment. ${ }^{33}$ All of these findings suggest that exhaled NO may reflect airway inflammation in asthma, and may be used as a means of monitoring inflammatory events in the lower airways.

\section{BRONCHIECTASIS}

Raised levels of exhaled NO have also been detected in patients with bronchiectasis, and the level of NO is related to the extent of disease as measured by a computed tomography score. ${ }^{17}$ As in asthma, the increase in exhaled NO is not seen in patients treated with inhaled steroids. ${ }^{17}$ This suggests that exhaled NO in bronchiectasis may reflect active inflammation in the lower airways and may be used to monitor disease activity.

Limited studies in patients with cystic fibrosis have shown increased levels of exhaled NO in some patients during exacerbations but in most patients normal levels have been found, probably due to the fact that most patients are treated with inhaled steroids (S Kharitonov et al, unpublished observations). There are also anecdotal reports of an increase in exhaled NO in association with lower respiratory tract infections. ${ }^{11}$

\section{VASCULAR DISEASE}

In patients with pulmonary hypertension secondary to systemic sclerosis there is a reduction in exhaled NO compared with normal subjects and with patients with interstitial lung disease without pulmonary hypertension. ${ }^{39}$ This may be a reflection of the reduced ecNOS expression described in patients with pulmonary hypertension. ${ }^{40}$ The reduced endogenous production in the vessels of patients with pulmonary hypertension may contribute to the vasoconstriction of pulmonary vessels and to the increased proliferation of vascular smooth muscle cells in this condition. ${ }^{41}$

A reduction in exhaled NO has also been reported in systemic hypertension ${ }^{26}$; this is more difficult to explain, but may reflect a generalised defect in endothelial NOS function.

\section{NASAL DISEASE}

High concentrations of NO have been detected in the nose of normal individuals ${ }^{19202242}$ and very high concentrations in the paranasal sinuses. ${ }^{21}$ This may be inhaled into the lower respiratory tract and exhaled, and may contribute to the exhaled NO measured at the mouth. It was suggested that the high concentrations of NO may be derived from bacteria which colonise the nose, as higher values were found in patients with penicillinase-resistant Staphylcoccus aureus. ${ }^{19}$ Bacteria may stimulate the local production of $\mathrm{NO}$ by induction of NO synthase and bacteria themselves may synthesise NO. ${ }^{43-45}$ However, treatment of normal subjects with a course of antibiotics fails to reduce nasal NO concentrations. ${ }^{20}$ Increased levels of nasal NO have been described in patients with allergic and perennial rhinitis ${ }^{46}$ and may reflect allergic inflammation in the nose. Very low levels of NO have been detected in the nose of patients with Kartagener's syndrome in which there is a congenital defect in ciliary activity. ${ }^{20}$ Endogenous NO appears to be important in ciliary beating ${ }^{31}$ and, in the absence of NO, there may be ciliary stasis.

\section{Effects of treatment}

Exhaled NO levels are significantly lower in patients with asthma and bronchiectasis who are treated with inhaled glucocorticoids, suggesting that inhaled steroids reduce exhaled NO. ${ }^{1217}$ An oral glucocorticoid, prednisolone (30 $\mathrm{mg}$ for three days), has no effect on exhaled NO in normal individuals, but decreases the raised levels of exhaled NO in asthmatic patients. ${ }^{47}$ This suggests that the exhaled NO in normal subjects is derived from constitutive NOS (unaffected by steroids), whereas the raised levels in asthma are derived from iNOS which is inhibited by glucocorticoids. In asthmatic patients a double blind study of inhaled budesonide has shown a progressive reduction in exhaled NO down to normal values after three weeks of treatment. ${ }^{48}$ The reduction in exhaled NO was progressive and may reflect direct inhibitory effects of glucocorticoids on induction of iNOS via a direct blockade of the transcription factor nuclear factor-kappa B (NF- $\kappa \mathrm{B})$, and an indirect effect due to reduced synthesis of the proinflammatory cytokines that leads to iNOS expression in airway epithelial cells. Biopsy studies have confirmed that iNOS expression in asthmatic airway epithelial cells is reduced in patients treated with inhaled steroids. ${ }^{49} \mathrm{NO}$ production in patients with rhinitis, measured by concentration of nitrite and nitrate in nasal lavage fluid, is apparently unaffected by topical glucocorticoids, suggesting that nasal NO may not be derived from iNOS or originates from cells that cannot be reached by topically applied steroids. ${ }^{50} \mathrm{NO}$ is produced in high concentrations by an enzyme expressed in paranasal sinuses that has similarities to iNOS but does not appear to be repressed by glucocorticoids. ${ }^{21}$

By contrast, neither short-acting nor long-acting inhaled $\beta_{2}$ agonists reduce exhaled NO in asthmatic patients. ${ }^{51}$ This is in keeping with other studies showing no antiinflammatory effect of inhaled $\beta_{2}$ agonists in asthma ${ }^{5253}$ and adds further support to the view that exhaled NO may be useful in assessing the anti-inflammatory effect of inhaled asthma treatments.

Several analogues of $\mathrm{L}$-arginine such as $\mathrm{N}^{\mathrm{G}}$-monomethyl$\mathrm{L}$-arginine (L-NMMA) and $\mathrm{N}^{\mathrm{G}}$-nitro-L-arginine methyl ester (L-NAME) act as false substrates and block NOS activity. These NOS inhibitors have been invaluable in investigating the role of endogenous NO in animal models and may have some therapeutic potential. Single inhalations of L-NMMA and L-NAME (via a nebuliser) result in reduced exhaled $\mathrm{NO}$ in normal and asthmatic patients. ${ }^{124754}$ Interestingly, there is no fall in $\mathrm{FEV}_{1}$, even in asthmatic patients with highly reactive airways, suggesting that basal production of NO is not important in basal airway tone. Although infusion of L-NMMA in normal subjects causes an increase in blood pressure, ${ }^{556}$ nei- 
ther nebulised L-NAME nor L-NMMA have any effect on heart rate or blood pressure, suggesting that inhibition of NOS is confined to the respiratory tract. While L-NMMA and L-NAME are non-selective inhibitors of cNOS and iNOS, aminoguanidine has some selectivity for iNOS. ${ }^{5758}$ Inhalation of aminoguanidine has no effect on exhaled NO in normal subjects, but significantly reduced exhaled NO in patients with asthma, ${ }^{54}$ adding further support to the view that the increased level of exhaled NO in asthma is derived from iNOS.

\section{Source of NO in exhaled air}

The cellular source of NO in the lower respiratory tract is not yet certain. Studies with perfused porcine lungs suggest that exhaled NO originates at the alveolar surface, rather than from the pulmonary circulation, ${ }^{59}$ and may be derived from ecNOS expressed in the alveolar walls or normal lungs. ${ }^{5}$ Studies in ventilated perfused lungs of guinea pigs show that exhaled NO is reduced during perfusion with calcium-free solutions, suggesting that $\mathrm{NO}$ is derived fiom a constitutive NOS which is calcium dependent. ${ }^{14}$ Airway epithelial cells may also express both ecNOS and nNOS and therefore contribute to $\mathrm{NO}$ in the lower respiratory tract. $^{6061}$ In inflammatory diseases it is likely that the increase in exhaled NO is due to induction of iNOS. Indeed, increased NOS activity has been found in lung tissue of patients with asthma, cystic fibrosis, and obliterative bronchiolitis. ${ }^{62}$ In asthmatic patients there is evidence for expression of iNOS in airway epithelial cells. ${ }^{6}$ Proinflammatory cytokines result in the expression of iNOS in murine epithelial cells and cultured human airway epithelial cells, ${ }^{616364}$ and it is likely that these same cytokines are released in asthmatic inflammation. iNOS may be expressed in other cell types such as alveolar macrophages and other inflammatory cells, although this has not been observed in biopsy tissue from the proximal airways of asthmatic patients. ${ }^{6}$ Furthermore, glucocorticoids inhibit the induction of iNOS in epithelial cells in vitro ${ }^{6364}$ and in vivo $^{49}$ and reduce exhaled NO levels in asthmatic patients to normal. ${ }^{48}$ In bronchiectasis there is some evidence for iNOS expression in the macrophages of affected lung. ${ }^{7}$

The levels of NO in the nose and nasopharynx are much higher than those recorded in expiration at the mouth, suggesting that the upper airways may be the major contributor to exhaled NO, at least in normal individuals. ${ }^{1920222342}$ Inhalation of high concentrations of NO gas has no effect on exhaled NO in normal subjects after a breath hold of 30-60 seconds, suggesting that there is a rapid uptake of NO in the respiratory tract. ${ }^{12}$ This suggests that the upper airways may not make a major contribution to the exhaled NO measured from the lower airways. The lower respiratory tract is likely to contribute some of the exhaled NO, even in normal individuals. NO has been detected in the exhaled air of tracheotomised rabbits, rats, guinea pigs, and humans, ${ }^{919}$ and by bronchoscopy in normal individuals. ${ }^{23}$ The products of NO metabolism nitrite and nitrothiols - are also present in bronchoalveolar lavage fluid of normal subjects. ${ }^{65}$ Simultaneous measurement of expired $\mathrm{CO}_{2}$ and $\mathrm{NO}$ demonstrates that the peak in exhaled NO precedes the peak value of $\mathrm{CO}_{2}$ (end tidal), suggesting that $\mathrm{NO}$ is derived from the airways rather than the alveoli. ${ }^{13}$ Although it is likely that nasal NO contributes to the levels of exhaled NO in normal individuals, it is unlikely to contribute to the increased levels found in inflammatory airway disease. Direct sampling via fibreoptic bronchoscopy in asthmatic patients shows a similar increase in NO in the trachea and main bronchi to that recorded at the mouth, thus indicating that the increased levels in asthma are derived from the lower airways. ${ }^{23}$ Indeed, there is a close relationship between the levels of NO measured in the bronchi and those measured at the mouth. ${ }^{23}$

\section{Functional relevance of exhaled NO}

NO gas may be a useful marker of airway and pulmonary disease, but it may also play a physiological and pathophysiological role. Tihe high concentrations of NO generated in the paranasal sinuses may have a sterilising effect in the sinuses and upper respiratory tract, since NO is toxic to bacteria, parasites, and viruses. ${ }^{66} \mathrm{NO}$ derived from the lower respiratory tract may also contribute to host defence, and the fact that iNOS can be rapidly expressed in airway epithelial cells provides a rapid non-specific defence mechanism in the respiratory tract. Knock out mice that lack the iNOS gene have a marked increase in susceptibility to infections. ${ }^{67}$

$\mathrm{NO}$ in the respiratory tract may also have an effect on the bronchial and pulmonary circulations. NO is a potent vasodilator and the increased production of $\mathrm{NO}$ in asthmatic airways may underlie the hyperaemia seen in the airways of these patients. Inhalation of high concentrations of NO from the upper respiratory tract, and that derived from the lower respiratory tract, may have effects on ventilation/perfusion $(\dot{V} / \dot{Q})$ matching within the lungs. Thus, in inflammatory conditions such as asthma there may be increased $\dot{V} / \dot{Q}$ matching due to pulmonary vasodilatation in response to autoinhalation of endogenously generated NO, resulting in increased hypoxaemia due to shunting. The role of endogenous $\mathrm{NO}$ in $\dot{\mathrm{V}} / \mathbf{Q}$ matching remains to be determined.

Although endogenous NO appears to be the major bronchodilator neurotransmitter in humans, ${ }^{6869}$ high concentrations of inspired NO have only weak bronchodilator effects $^{7071}$ so it is unlikely that endogenous NO is an important determinant of airway calibre. Indeed, marked inhibition of endogenous NO production by nebulised NOS inhibitors has no detectable effect on airway function even in patients with asthma. ${ }^{4754}$

\section{Future directions}

The measurement of exhaled NO has excited considerable interest as it may provide a simple non-invasive means of measuring airway inflammation. There is now persuasive evidence that levels of $\mathrm{NO}$ are increased in association with airway inflammation and are decreased by anti-inflammatory treatments. Correlation of exhaled NO with more direct measurements of inflammation in the airways - such as induced sputum, bronchoalveolar lavage, and bronchial biopsies - is needed. The great advantage of exhaled NO is that the measurement is completely noninvasive and can therefore be performed repeatedly and also in children and patients with severe airflow obstruction where more invasive techniques are not possible. The measurement, however, is not specific and exhaled NO is increased in inflammation due to asthma, bronchiectasis, and respiratory tract infections. This means that absolute values are less important than serial measurements in individual patients. The value of this approach has been demonstrated in asthmatic patients where the dose of inhaled steroid is changed, resulting in increased levels when the dose is reduced and lower levels when the dose is increased. ${ }^{38}$ Because exhaled NO is reduced by antiinflammatory treatments, it may be useful for monitoring whether treatment is adequate. The technique may also be used in the monitoring of anti-inflammatory effects of new anti-asthma drugs such as selective phosphodiesterase inhibitors, leukotriene antagonists, synthesis inhibitors, and immunomodulators. Because the measurement is precise 
and reasonably reproducible, it may facilitate the measurement of dose-response effects with anti-inflammatory treatments that is difficult at present.

The currently available analysers for exhaled NO are expensive, but it is likely that technological advances will make it possible to miniaturise these analysers so that they are portable and may even be used at home in conjunction with peak flow meters. This may lead to their application in epidemiological studies and they may be useful screening measurements for community studies.

Although we have discussed exhaled NO, other volatile substances may also be detected in exhaled air. Thus, ethane and pentane (which are volatile products of lipid peroxidation) and hydrogen peroxide may be used to detect oxidant stress in the respiratory tract and may also be useful as markers of inflammation. ${ }^{7273}$ There is little doubt that this is a rapidly expanding area of research.

Department of Thoracic Medicine, National Heart and Lung Institute, Dovehouse Street, London SW3 6LY, UK

1 Barnes PJ, Belvisi MG. Nitric oxide and lung disease. Thorax 1993;48 1034-43.

2 Gaston B, Drazen JM, Loscalzo J, Stamler JS. The biology of nitrogen oxides in the airways. Am $\mathcal{F}$ Respir Crit Care Med 1994;149:538-51.

3 Barnes C, Liew FY. Nitric oxide and asthmatic inflammation. Immunol Today 1995;16:128-30.

4 Nathan C, Xie Q. Regulation of biosynthesis of nitric oxide. 7 Biol Chem 1994;269:13725-8.

5 Kobzik L, Bredt DS, Lowenstein CJ, Drazen J, Gaston B, Sugarbaker D, et al. Nitric oxide synthase in human and rat lung: immunocytochemical and histochemical localization. Am f Respir Cell Mol Biol 1993;9:371-7.

6 Hamid Q, Springall DR, Riveros-Moreno V, Chanez P, Howarth P, Redington A, et al. Induction of nitric oxide synthase in asthma. Lancet 1993; 342:1510-3

7 Tracey WR, Xue C, Klinghoffer V, Barlow J, Pollock JS, Förstermann U, et al. Immunocytochemical detection of inducible NO synthase in human lung. Am f Physiol 1994;266:L722-7.

8 Ward JK, Belvisi MG, Springall DR, Abelli L, Tadjkarimi S, Yacoub MH, et al. Human iNANC bronchodilatation and nitric oxide-immunoreactive nerves are reduced in distal airways. Am 7 Respir Cell Mol Biol 1995;13. nerves are $175-84$.

9 Gustafsson LE, Leone AM, Persson M, Wiklund NP, Moncada S. Endogenous nitric oxide is present in the exhaled air of rabbits, guinea-pigs and humans. Biochem Biophys Res Commun 1991;181:852-7.

10 Borland C, Cox Y, Higenbottam T. Measurement of exhaled nitric oxide in man. Thorax 1993;48:1160-2.

11 Alving K, Weitzberg E, Lundberg JM. Increased amount of nitric oxide in exhaled air of asthmatics. Eur Respir f 1993;6:1268-70.

12 Kharitonov SA, Yates D, Robbins RA, Logan-Sinclair R, Shinebourne E, Barnes PJ. Increased nitric oxide in exhaled air of asthmatic patients. Lancet 1994;343:133-5.

13 Persson MG, Wiklung NP, Gustafsson LE. Endogenous nitric oxide in single exhalation, and the change during exercise. Am Rev Respir Dis 1993;148:1210-4.

14 Persson MG, Midtvedt T, Leone AM, Gustafsson LE. $\mathrm{Ca}^{2+}$-dependent and $\mathrm{Ca}^{2+}$-independent exhaled nitric oxide, presence in germ-free animals and inhibition by arginine analogues. Eur f Pharmacol 1994;264:13-20.

15 Leone AM, Gustafsson LE, Francis PL, Persson MG, Wiklund NP, Moncada S. Nitric oxide in exhaled breath in humans: direct GC-MS confirmation. Biochem Biophys Res Commun 1994;201:883-7.

16 Persson MG, Zetterström O, Argenius V, Ihre E, Gustafsson LE. Singlebreath oxide measurements in asthmatic patients and smokers. Lancet 1994;343:146-7.

17 Kharitonov SA, Wells AU, O'Connor BJ, Hansell DM, Cole PJ, Barnes PJ. Elevated levels of exhaled nitric oxide in bronchiectasis. Am $\mathcal{f}$ Respir Crit Care Med 1995;151:1889-93.

18 Archer S. Measurement of nitric oxide in biological models. FASEB 71993 ; 7:349-60.

19 Gerlach H, Rossaint R, Pappert D, Knorr M, Falke KJ. Autoinhalation of nitric oxide after endogenous synthesis in nasopharynx. Lancet 1994;343 518-9.

20 Lundberg JON, Weitzberg E, Nordvall SL, Kuylenstierna R, Lundberg JM, Alving K. Primarily nasal origin of exhaled nitric oxide and absence in Alving K. Primarily nasal origin of exhaled nitric oxide
Kartagener's syndrome. Eur Respir $\mathcal{F} 1994 ; 8: 1501-4$

21 Lundberg JON, Farkas-Szallasi T, Weitzberg E, Rinder J, Lidholm J, Änggard A, et al. High nitric oxide production in human paranasal sinuses. Änggard A, et al. High nitric

22 Kimberley B, Nejadnik B, Giraud GD, Holden We. Nasal contribution to exhaled nitric oxide at rest and during breath holding in humans. Am $\mathcal{F}$ Respir Crit Care Med 1995;152:(in press).

23 Kharitonov S, Chung KF, Evans DJ, Logan-Sinclair R, O'Connor BJ, Barnes PJ, The elevated level of exhaled nitric oxide in asthmatic patient is mainly derived from the lower respiratory tract. Eur Respir $\mathcal{F} 1995 ; 8$ $377 \mathrm{~S}$.

24 Kharitonov SA, Yates D, Barnes PJ. Increased nitric oxide in exhaled air of normal human subjects with upper respiratory tract infections. Eur Respir $\mathcal{F}$ 1995;8:295-7.

25 Kharitonov SA, Lubec G, Lubec B, Hjelm M, Barnes PJ. L-Arginine increases exhaled nitric oxide in normal human subjects. Clin Sci 1995; 88:135-9.
26 Schilling J, Holzer P, Guggenbach M, Gyurech D, Marathia K, Geroulanos $\mathrm{S}$. Reduced endogenous nitric oxide in the exhaled air of smokers and hypertension. Eur Respir $\mathcal{F}$ 1994;7:467-71.

27 Kharitonov SA, Robbins RA, Yates D, Keatings V, Barnes PJ. Acute and chronic effects of cigarette smoking on exhaled nitric oxide. Am $\mathcal{F}$ Respir Crit Care Med 1995;152:609-12.

28 Buga GM. Griscavage JM, Rogers NE, Ignarro LJ. Negative feedback regulations of endothelial cell function by nitric oxide. Circ Res 1993;73 808-12.

29 Assreuy J, Cunha FQ, Liew FY, Moncada S. Feedback inhibition of nitric oxide synthase by nitric oxide. Br F Pharmacol 1993;108:833-7.

30 Rengasamy A, Johns RA. Regulation of nitric oxide synthase by nitric oxide. Mol Pharmacol 1993;44:124-8.

31 Jain B, Lubinstein I, Robbins RA, Leise KL, Sisson JH. Modulation of airway epithelial cell ciliary beat frequency by nitric oxide. Biochem Biophys Res Commun 1993;191:83-8.

32 Robbins RA, Floreani AA, van Essen SG, Sisson JH, Hill GE, Rubenstein $\mathrm{I}$, et al. Measurement of nitric oxide by three different techniques. $A m \mathfrak{I}$ Respir Crit Care Med 1995;152:(in press).

33 Massaro AF, Gaston B, Kita D, Fanta C, Stamler J, Drazen JM. Expired nitric oxide levels during treatment for acute asthma. Am f Respir Cri Care Med 1995;152:800-3.

34 Kharitonov SA, O'Connor BJ, Evans DJ, Barnes PJ. Allergen-induced late asthmatic reactions are associated with elevation of exhaled nitric oxide. Am f Respir Crit Care Med 1995;151:1894-9.

35 Endo $T$, Uchida $Y$, Nomura A, Ninomiya $H$, Sakamoto $T$, Hasegawa $S$. Increased production of nitric oxide in the immediate and late response models of guinea pig experimental asthma. Am $\mathcal{F}$ Respir Crit Care Med 1995;151:A177.

36 Kharitonov SA, Evans DJ, Barnes PJ, O'Connor BJ. Bronchial provocation challenge with histamine or adenosine $5^{\prime}$ monophosphate does not alter exhaled nitric oxide in asthma. Am 7 Respir Crit Care Med 1995;151:A125.

37 Kharitonov SA, Yates D, Robbins RA, Logan-Sinclair R, Shinebourne EA Barnes PJ. Endogenous nitric oxide is increased in the exhaled air of asthmatic patients. Am f Respir Crit Care Med 1994;149:A198.

38 Kharitonov SA, Yates DH, Barnes PJ. Changes in the dose of inhaled budesonide affect exhaled nitric oxide levels in asthmatics. Am $\mathcal{F}$ Respir Crit Care Med 1995;151:A699.

39 Cailes JB, Kharitonov S, Yates D, Barnes P, Du Bois RM. Decreased endogenous nitric oxide in the exhaled air of systemic sclerosis patients. Thorax 1995;50:452P.

40 Giaid A, Saleh D. Reduced expression of endothelial nitric oxide synthase in the lungs of patients with pulmonary hypertension. $N$ Engl f Med 1995; 333:214-21

41 Barnes PJ, Liu S. Regulation of pulmonary vascular tone. Pharmacol Rer 1995;47:87-118.

42 Du Bois AB, Douglas JS, Leaderer BP, Mohsenin V. The presence of nitric oxide in the nasal cavity of normal humans. Am $\mathcal{F}$ Respir Crit Care Med 1994;149:A197.

43 Heiss LN, Lancaster JR, Corbett JA, Goldman WE. Epithelial autotoxicity of nitric oxide: role in the respiratory cytopathology of pertussis. Proc Nat Acad Sci USA 1994;91:267-70.

44 Vosswinkel R, Neidt I, Bothe $\mathrm{H}$. The production and utilization of nitric oxide by a new denitrifying strain of Pseudomonas aeuruginosa. Arch Microbiol 1991;156:62-9.

45 Cannons AC, Barber MJ, Solomonson LP. Expression and characterization of the home-binding domain of Chlorella nitrate reductase. 7 Biol Chem 1993;268:3268-71.

46 Martin U, Bryden K, Devoy M, Howarth PH. Exhaled nitric oxide levels are increased in association with symptoms of seasonal and perennia rhinitis. Am $\mathcal{F}$ Respir Crit Care Med 1995;151:A128.

47 Yates DH, Kharitonov SA, Robbins RA, Thomas PS, Barnes PJ. Effect of a nitric oxide synthase inhibitor and a glucocorticosteroid on exhaled nitric oxide. Am f Respir Crit Care Med 1995;152:892-6.

48 Kharitonov SA, Yates DH, Barnes PJ. Regular inhaled budesonide decreases nitric oxide concentration in the exhaled air of asthmatic patients. $A m \mathcal{F}$ Respir Crit Care Med 1995;152:(in press).

49 Springall DR, Meng Q, Redington A, Howarth PH, Evens TJ, Polak JM Inducible nitric oxide synthase in asthmatic airway epithelium is reduced by corticosteroid therapy. Am F Respir Crit Care Med 1995;151:A833.

50 Garrelds IM, van Amsterdam JGC, de Graff-in't Veld C, van Wijk G Zijlstra MN. Nitric oxide metabolites in nasal lavage fluid of patients with house dust mite allergy. Thorax 1995;50:275-9.

51 Yates DH, Kharitonov SA, Scott DM, Worsdell M, Barnes PJ. Short and long acting $\beta_{2}$-agonists do not alter exhaled nitric oxide in asthma. $A m \mathcal{F}$ Respir Crit Care Med 1995;151:A129.

52 Laitinen LA, Laitinen A, Haahtela T. A comparative study of the effects of an inhaled corticosteroid, budesonide, and of a $\beta_{2}$-agonist, terbutaline,
on airway inflammation in newly diagnosed asthma. $\mathcal{F}$ Allergy Clin Immunol on airway inflam

53 Gardiner PV, Ward C, Booth H, Allison A, Hendrick DJ, Walters EH Effect of eight weeks of treatment with salmeterol on bronchoalveolar lavage inflammatory indices in asthmatics. Am $\mathcal{F}$ Respir Crit Care Med 1994;150:1006-11.

54 Yates DH, Kharitonov SA, Worsdell M, Thomas PS, Barnes PJ. Exhaled nitric oxide is decreased after inhalation of a specific inhibitor of inducible nitric oxide synthase, in asthmatic but not in normal subjects. Am $\mathcal{F}$ Respir Crit Care Med 1995;151:A699.

55 Haynes WG, Noon JP, Walker BR, Webb DJ. Inhibition of nitric oxide synthesis increases blood pressure in healthy humans. $\mathcal{F}$ Hypertension 1993 11:1375-80.

56 Stammler JS, Loh E, Roddy M, Currie XE, Creager MA. Nitric oxide regulates broad systemic and pulmonary vascular resistance in normal regulates broad systemic and pulmonar

57 Misko TP, Moore WM, Kasten TP, Nickols GA, Corbett JA, Tilton RG, is al Sective inhibition of inducible nitric synthase by aminoguanidine. et al. Selective inhibition of inducib.
Eur $\mathcal{F}$ Pharmacol 1993;233:119-25.

58 Hasan K, Heeson BJ, Corbett JA, McDaniel ML, Chang K, Allison W, e al. Inhibition of nitric oxide formation by guanidines. Eur $\mathcal{F}$ Pharmaco 1993;249:101-6.

59 Cremona G, Higenbottam T, Takao M, Hall L, Bower EA. Exhaled nitric oxide in isolated pig lungs. $\mathcal{A}$ Appl Physiol 1995;78:59-63.

60 Shaul PW, North AJ, Wu LC, Wells LB, Brannon B, Lau KS, et al. Endothelial nitric oxide synthase is expressed in cultured bronchiola epithelium. $\mathcal{f}$ Clin Invest 1994;94:2231-6. 
61 Asano K, Chee CBE, Gaston B, Lilly CM, Gerard C, Drazen JM, et al. Constitutive and inducible nitric synthase gene expression, regulation and activity in human lung epithelial cells. Proc Natl Acad Sci USA 1994;91: 10089-93.

62 Belvisi MG, Barnes PJ, Larkin S, Yacoub M, Tadjkarimi S, Williams TJ, et al. Nitric oxide synthase activity is elevated in inflammatory lung diseases. Eur f Pharmacol 1995;283:255-8.

63 Robbins RA, Springall DR, Warren JB, Kwon OJ, Buttery LDK, Wilson $\mathrm{AJ}$, et al. Inducible nitric oxide synthase is increased in murine lung epithelial cells by cytokine stimulation. Biochem Biophys Res Commun 1994;198: 1027-33.

64 Robbins RA, Barnes PJ, Springall DR, Warren JB, Kwon OJ, Buttery LDK, et al. Expression of inducible nitric oxide synthase in human bronchial epithelial cells. Biochem Biophys Res Commun 1994;204:209-18.

65 Gaston B, Reilly J, Drazen JM, Fackler J, Ramden P, Arnelle D, et al. Endogenous nitrogen oxides and bronchodilator S-nitrosolthiols in human airways. Proc Natl Acad Sci USA 1993;90:10957-61.

66 Liew FY, Cox FF. Nonspecific resistance mechanisms: the role of nitric oxide. Immunology Today 1991;12:A17-21.
67 Wei X, Charles IG, Smith A, Ure J, Feng G, Huang F, et al. Altered immune responses in mice lacking inducible nitric oxide synthase. Nature 1995;375:408-11.

68 Belvisi MG, Stretton CD, Barnes PJ. Nitric oxide is the endogenous neurotransmitter of bronchodilator nerves in human airways. Eur f Pharmacol 1992;210:221-2.

69 Ward JK, Belvisi MG, Fox AJ, Miura M, Tadjkarimi S, Yacoub MH, et al. Modulation of cholineroic neural bronchoconstriction by endogenous nitric oxide and vasoactive intestinal peptide in human airways in vitro. f Clin Invest 1993;92:736-43.

70 Högman M, Frostell CG, Hedenström H, Hedenstierna G. Inhalation of nitric oxide modulates adult human bronchial tone. Am Rev Respir Dis 1993;148:1474-8.

71 Sanna A, Kurtansky A, Veriter C, Stanescu D. Bronchodilator effect of inhaled nitric oxide in healthy men. Am $\mathcal{F}$ Respir Crit Care Med 1994;150:

72 Habib MP, Clements NC, Garewal HS. Cigarette smoking and ethane exhalation in humans. Am $\mathcal{F}$ Respir Crit Care Med 1995;151:1368-72

73 Dohlman AW, Black HR, Royall JA. Expired breath hydrogen peroxide is a marker of acute airway inflammation in pediatric patients with asthma. 